\title{
Evaluation of 2,3-Butanediol Production from Red Seaweed Gelidium amansii Hydrolysates Using Engineered Saccharomyces cerevisiae
}

\author{
Chae Hun $\mathrm{Ra}^{1}$, Jin-Ho Seo ${ }^{2}$, Gwi-Taek Jeong ${ }^{3}$, and Sung-Koo Kim ${ }^{3 *}$ \\ ${ }^{1}$ Department of Food Science and Biotechnology, College of Engineering, Global K-Food Research Center, \\ Hankyong National University, Anseong 17579, Republic of Korea \\ ${ }^{2}$ Department of Agricultural Biotechnology and Center for Food and Bioconvergence, Seoul National University, \\ Seoul 08826, Republic of Korea \\ ${ }^{3}$ Department of Biotechnology, Pukyong National University, Busan 48513, Republic of Korea
}

\begin{abstract}
Hyper-thermal (HT) acid hydrolysis of red seaweed Gelidium amansii was performed using $12 \%$ (w/v) slurry and an acid mix concentration of $180 \mathrm{mM}$ at $150^{\circ} \mathrm{C}$ for $10 \mathrm{~min}$. Enzymatic saccharification when using a combination of Celluclast $1.5 \mathrm{~L}$ and CTec2 at a dose of $16 \mathrm{U} / \mathrm{ml}$ led to the production of $12.0 \mathrm{~g} / \mathrm{l}$ of reducing sugar with an efficiency of enzymatic saccharification of $13.2 \%$. After the enzymatic saccharification, 2,3-butanediol (2,3-BD) fermentation was carried out using an engineered S. cerevisiae strain. The use of HT acid-hydrolyzed medium with $1.9 \mathrm{~g} / \mathrm{l}$ of 5-hydroxymethylfurfural showed a reduction in the lag time from 48 to $24 \mathrm{~h}$. The 2,3-BD concentration and yield coefficient at $72 \mathrm{~h}$ were $14.8 \mathrm{~g} / \mathrm{l}$ and 0.30 , respectively. Therefore, $\mathrm{HT}$ acid hydrolysis and the use of the engineered $S$. cerevisiae strain can enhance the overall 2,3-BD yields from $G$. amansii seaweed.
\end{abstract}

Keywords: Hyper-thermal acid hydrolysis, enzymatic saccharification, Gelidium amansii, 2,3-butanediol, engineered Saccharomyces cerevisiae

Received: July 28, 2020 Accepted: September 18, 2020

First published online: September 22, 2020

*Corresponding author Phone +82-51-629-5868 Fax: + 82-51-629 5863 E-mail: skkim@pknu.ac.kr

pISSN 1017-7825 elSSN 1738-8872

Copyright(C) 2020 by The Korean Society for Microbiology and Biotechnology

\section{Introduction}

An increase in public awareness in regard to renewable energy and climate change has led to a growing interest in the use of microbial fermentation technologies for the production of biofuels and chemicals $[1,2]$. The microbial production of 2,3-butanediol (2,3-BD) is one such example, as 2,3-BD has a large number of industrial applications; for example, it can be used as an antifreeze agent due to a low freezing point of $-60^{\circ} \mathrm{C}[3]$. Moreover, the production of 2,3-BD via microbial fermentation can alleviate the dependence on oil supplies for the production of platform chemicals [4]. Additionally, 2,3-BD has other potential applications, such as the manufacturing of printing inks, perfumes, moistening and softening agents, explosives, plasticizers, foods, and pharmaceuticals [5].

Marine biomass, such as algae and seaweed, can be a potential resource for the biochemical production of biofuel, as it does not contain lignin and has a high carbohydrate content and a fast growth rate, as well as having the ability to fix large amounts of carbon dioxide [6]. In particular, up to 58\% of the dry weight of the red algae Gelidium amansii is composed of carbohydrates such as agar (galactan) and cellulose. Agar is composed of galactose and 3,6-anhydrogalactose (AHG). Thus, the G. amansii hydrolysate, which contains a high amount of glucose and galactose, can be used as a substrate for the microbial production of 2,3-BD.

In this study, we used hyper-thermal (HT) acid hydrolysis to yield high concentrations of monosaccharides and low concentrations of inhibitory compounds. Moreover, several factors that influence hydrolysis efficiency were evaluated, including acid types and concentrations, temperature, thermal hydrolysis time, and slurry concentration. Additionally, we used enzymatic saccharification to hydrolyze the remaining cellulose for glucose production.

Until now, Klebsiella pneumoniae, Enterobacter aerogenes, Bacillus sp. and Serratia marcescens have been considered promising for the efficient production of 2,3-BD. However, Saccharomyces cerevisiae has many advantages over bacteria for industrial use and significant research efforts have focused on the production of 2,3$\mathrm{BD}$ by engineered $S$. cerevisiae harboring the bacterial $2,3-\mathrm{BD}$ biosynthetic enzymes $[7,8]$. The pyruvate decarboxylase (Pdc)-deficient $S$. cerevisiae strain provides a promising metabolic background for the production of non-ethanol products, such as 2,3-BD [7], 3-hydroxypropionic acid [9], and lactic acid [10]. This strain accumulates pyruvate, which is a precursor of numerous chemical molecules, instead of producing ethanol from 
glucose [11]. Therefore, in this study, the evolved Pdc-deficient S. cerevisiae strain expressing the 2,3-BD synthetic enzymes was evaluated to investigate its 2,3-BD production capacity using G. amansii hydrolysate.

\section{Materials and Methods}

\section{Microbial Strains and Culture Medium}

The evolved 2,3-BD-producing S. cerevisiae strain used in this study was obtained from the Agricultural Biotechnology and Center for Food and Bioconvergence (Seoul National University, Seoul, Republic of Korea). An engineered S. cerevisiae strain (BD4) capable of efficient production of 2,3-BD was constructed through the elimination of the pyruvate decarboxylase genes ( $\triangle P D C 1$ and $\triangle P D C 5)$, overexpression of acetolactate synthase $(a l s S)$ and acetolactate decarboxylase $(a l s D)$, and overexpression of 2,3-butanediol dehydrogenase (BDH1) [7]. The seed cultures were prepared according to procedures described by Kim et al. and Choi et al. [7, 12]. Yeast cells were cultured at $30^{\circ} \mathrm{C}$ and $150 \mathrm{rpm}$ for $24 \mathrm{~h}$ in pre-culture yeast synthetic complete (YSC) medium containing $6.7 \mathrm{~g} / \mathrm{l}$ yeast nitrogen base (YNB), $20 \mathrm{~g} / \mathrm{l}$ glucose, and $1 \mathrm{~g} / \mathrm{l}$ ethanol.

The growth medium for the Pdc-deficient strains was supplemented with two carbon $\left(\mathrm{C}_{2}\right)$ compounds, such as acetate or ethanol, in order to enable the synthesis of lysine and fatty acids [11, 13]. After being cultured for $24 \mathrm{~h}$, the cells in the mid-exponential growth phase were used for the main culture of the yeast strains.

Gelidium amansii (product of Morocco) was obtained from Biolsystems Co., Ltd. (Republic of Korea). The composition of G. amansii was analyzed by the Feed and Foods Nutrition Research Center of Pukyong National University (Republic of Korea) according to the method provided by the Association of Official Analytical Chemists (AOAC) [14]. Thus, the amounts of carbohydrates and cellulose were used to calculate the efficiency of the pretreatment and enzymatic saccharification.

\section{Hyper-Thermal Acid Hydrolysis Pretreatment}

One-factor-at-a-time (OFAT) experiments were carried out to determine the settings for the indicated main factors [15]. HT acid hydrolysis was performed by changing the pretreatment parameters, such as the $\mathrm{H}_{2} \mathrm{SO}_{4}$, $\mathrm{H}_{3} \mathrm{PO}_{4}, \mathrm{HCl}$, and $\mathrm{HNO}_{3}$ concentrations, to between 45-720 mM. Meanwhile, temperatures were in the range of $120-180^{\circ} \mathrm{C}$, thermal hydrolysis times between $5-20 \mathrm{~min}$, and seaweed slurry concentrations between $8-20 \%(\mathrm{w} / \mathrm{v})$.

The HT acid hydrolysis pretreatment was initiated by raising the reactor temperature in an oil bath. The reaction was performed using a 50-ml stainless steel batch reactor with a working volume of $40 \mathrm{ml}$. The stainless steel reactor was filled with the indicated amounts of seaweed slurry and acids. A magnetic stirrer was placed inside the reactor to maintain efficient contact between the seaweed slurry and the acids. The temperature was monitored and adjusted with a proportional-integral-derivative (PID) temperature controller (TC200P; Misung Scientific Co., Ltd., Republic of Korea). After pretreatment, the reactor was quickly cooled in cold water. The HT acid hydrolysis pretreatment efficiency $\left(E_{\mathrm{p}}\right.$, \%) was calculated using Eq. (1):

$$
E_{\mathrm{P}}(\%)=\frac{\Delta \mathrm{S}_{\mathrm{RS}}}{\mathrm{TC}} \times 100
$$

where $\Delta \mathrm{S}_{\mathrm{RS}}$ is the increase in reducing sugar concentration $(\mathrm{g} / \mathrm{l})$ during HT acid hydrolysis and TC is the total carbohydrate (g/l) content of carbohydrates and cellulose in the pretreated G. amansii.

\section{Enzymatic Saccharification}

After HT acid hydrolysis, the $\mathrm{pH}$ of the pretreated G. amansii mixture was adjusted to 5.0 with $5 \mathrm{~N} \mathrm{NaOH}$. Enzymatic saccharification of the G. amansii hydrolysate was carried out using Viscozyme L ( $\beta$-glucanase, $121 \mathrm{U} / \mathrm{ml}$; Novozymes, Denmark), Celluclast $1.5 \mathrm{~L}$ (cellulase, $854 \mathrm{U} / \mathrm{ml}$; Novozymes), and Cellic CTec2 (cellulase, $150 \mathrm{U} / \mathrm{ml}$; Novozymes). The three enzymes used in this study are blended enzymes containing cellulase, $\beta$-glucanase (endo$1,3$ or 1,4$)$, and hemicellulose, as described in previous reports $[16,17]$. The three enzymes were then diluted and an enzyme concentration of $16 \mathrm{U} / \mathrm{ml}$ was used. The reaction was performed at $50^{\circ} \mathrm{C}$ and $150 \mathrm{rpm}$ for $48 \mathrm{~h}$ after $\mathrm{HT}$ acid hydrolysis. To achieve a synergistic effect compared with single enzyme treatments, the mixed enzymes were prepared at a 1:1 ratio with $16 \mathrm{U} / \mathrm{ml}$ of each enzyme. The efficiency of enzymatic saccharification $\left(E_{s}, \%\right)$ process was determined using Eq. (2).

$$
E_{\mathrm{s}}(\%)=\frac{\Delta \mathrm{S}_{\mathrm{RS}}}{\mathrm{TC}} \times 100
$$

where $\Delta \mathrm{S}_{\mathrm{RS}}$ represents the increase in reducing sugar concentration $(\mathrm{g} / \mathrm{l})$ during the enzymatic saccharification process and TC represents the concentration of total carbohydrates $(\mathrm{g} / \mathrm{l})$, namely carbohydrates and cellulose, in the pretreated G. amansii.

\section{Fermentation of 2,3-Butanediol}

After the enzymatic saccharification process, 2,3-BD fermentation was carried out using $100 \mathrm{ml}$ of the G. amansii hydrolysate in a 250-ml Erlenmeyer flask under semi-anaerobic conditions. Strictly anaerobic fermentation is normally carried out in a sealed, airtight fermenter or by gas packing with $\mathrm{N}_{2}$ gas. Thus, the term 'semi-anaerobic conditions' is applied due to the use of a non-airtight container. The G. amansii hydrolysates were supplemented with the following nutrients: $2.5 \mathrm{~g} / \mathrm{l} \mathrm{NH}_{4} \mathrm{Cl}, 5.0 \mathrm{~g} / \mathrm{l} \mathrm{K}_{2} \mathrm{HPO}_{4}, 0.25 \mathrm{~g} / 1 \mathrm{MgSO}_{4}$, and $3.0 \mathrm{~g} / \mathrm{l}$ yeast extract. The $\mathrm{pH}$ of the hydrolysate medium used for fermentation was adjusted to 6.3 by adding $5 \mathrm{~N} \mathrm{NaOH}$ before 
the inoculum was added. Ten $\mathrm{mL}$ of the engineered S. cerevisiae inoculum $(6.8 \mathrm{~g} \mathrm{dcw} / \mathrm{L})$ was transferred to the G. amansii hydrolysate and then the fermentation process was carried out at $30^{\circ} \mathrm{C}$ and $150 \mathrm{rpm}$. Samples were taken periodically and stored at $-20^{\circ} \mathrm{C}$ to determine the $2,3-\mathrm{BD}$, reducing sugar, glycerol, and 5-hydroxymethylfurfural (5-HMF) concentrations, as well as the $\mathrm{pH}$ and optical density. The 2,3-BD yield ( $\left.Y_{\mathrm{BD}}, \mathrm{g} / \mathrm{g}\right)$ was determined according to the following Eq. (3).

$$
Y_{\mathrm{BD}}(\%)=\frac{[2,3-\mathrm{BD}]_{\max }}{[\text { Reducing sugar }]_{\text {ini }}} \times 100
$$

where $[2,3-\mathrm{BD}]_{\max }$ is the highest $2,3-\mathrm{BD}$ concentration $(\mathrm{g} / \mathrm{l})$ obtained during the fermentation process and [Reducing sugar $]_{\mathrm{ini}}$ is the total initial reducing sugar concentration $(\mathrm{g} / \mathrm{l})$ at the start of the fermentation process.

\section{Analytical Methods}

The cell concentration was determined based on the correlation between the absorbance at $600 \mathrm{~nm}$ (Ultrospec 6300 Pro; Biochrom Ltd., UK) and the dry cell weight (g dcw/L). The reducing sugar concentration was determined using the 3,5-dinitrosalicylic acid (DNS) method with glucose (Sigma-Aldrich, USA) as the standard. The concentrations of 2,3-BD, glycerol, and 5-HMF were determined via high-performance liquid chromatography (HPLC, Agilent 1100 Series; Agilent Technologies, USA) using an Aminex HPX-87H column (Bio-Rad, USA). The detector was used to measure the refractive index. The mobile phase consisted of $5 \mathrm{mM} \mathrm{H}_{2} \mathrm{SO}_{4}$ at a flow rate of $0.6 \mathrm{ml} / \mathrm{min}$ at $65^{\circ} \mathrm{C}$. The values were reported as the means of triplicate experiments.

\section{Results and Discussion}

\section{Composition and Pretreatment of G. amansii}

The G. amansii samples were composed of $58.4 \%$ carbohydrates, $17.4 \%$ crude fiber, $18.7 \%$ crude protein, $0.7 \%$ crude lipids, and $4.8 \%$ crude ash. The total carbohydrate content of the G. amansii samples used in this study was $75.8 \%$, including the crude fibers, such as cellulose on a dry solid basis.

The HT acid hydrolysis pretreatment was carried out to determine the optimal acid type and combination ratios of $\mathrm{H}_{2} \mathrm{SO}_{4}, \mathrm{H}_{3} \mathrm{PO}_{4}, \mathrm{HCl}$, and $\mathrm{HNO}_{3}$, as shown in Fig. 1. The effects of the various acid concentrations used were determined at a temperature of $160^{\circ} \mathrm{C}$, thermal hydrolysis time of $15 \mathrm{~min}$, and $12 \%(\mathrm{w} / \mathrm{v})$ slurry as shown in Fig. 1A. Among the various acid treatments, $\mathrm{H}_{3} \mathrm{PO}_{4}$ produced the highest reducing sugar concentration with 33.4 $\mathrm{g} / \mathrm{l}$ and $E \mathrm{p}$ of $36.7 \%$. Moreover, reducing sugar concentrations of $26.5 \mathrm{~g} / \mathrm{l}\left(E_{\mathrm{p}}=29.1 \%\right), 27.0 \mathrm{~g} / \mathrm{l}\left(E_{\mathrm{p}}=29.7 \%\right)$, and $29.8 \mathrm{~g} / \mathrm{l}\left(E_{\mathrm{p}}=32.7 \%\right)$ were obtained when using $\mathrm{H}_{2} \mathrm{SO}_{4}, \mathrm{HCl}$, and $\mathrm{HNO}_{3}$, respectively. On the other hand, the use of $\mathrm{H}_{2} \mathrm{SO}_{4}, \mathrm{H}_{3} \mathrm{PO}_{4}, \mathrm{HCl}$, and $\mathrm{HNO}_{3}$ led to the production of 4.3, 9.8, 3.1, and $0.7 \mathrm{~g} / \mathrm{l}$ of inhibitory compounds, such as 5-HMF. Furfural and 5-HMF are fermentation inhibitors and their formation indicated the need for separate detoxification steps for 2,3-BD fermentation [18]. Li et al. [19] reported on the performance of different acids combined with different salts used to convert glucose to 5- $\mathrm{HMF}$. It was observed that $\mathrm{H}_{2} \mathrm{SO}_{4}, \mathrm{H}_{3} \mathrm{PO}_{4}$, and $\mathrm{HCl}$ produced a higher concentration of 5-HMF than $\mathrm{HNO}_{3}$. Thus, considering the conditions under which the maximum reducing sugar and minimum inhibitory compound concentrations were obtained, the combination of $\mathrm{H}_{3} \mathrm{PO}_{4}$ and $\mathrm{HNO}_{3}$ was selected as the suitable acid mixture for the $\mathrm{HT}$ acid hydrolysis pretreatment.

The effects of the ratio between $\mathrm{H}_{3} \mathrm{PO}_{4}$ and $\mathrm{HNO}_{3}$ on the production of reducing sugar and inhibitors are shown in Fig. 1B. The results showed that a 5:5 ratio between $\mathrm{H}_{3} \mathrm{PO}_{4}$ and $\mathrm{HNO}_{3}$ produced the highest reducing sugar concentration, with $35.3 \mathrm{~g} / \mathrm{l}$ and an $E_{\mathrm{p}}$ of $38.8 \%$. Moreover, when we increased the proportion of $\mathrm{H}_{3} \mathrm{PO}_{4}$, we found that the concentration of reducing sugar and 5-HMF was not greater than that obtained when using a 5:5 ratio. Therefore, a 5:5 ratio between $\mathrm{H}_{3} \mathrm{PO}_{4}$ and $\mathrm{HNO}_{3}$ was selected as the optimal acid combination.

Next, we determined the optimal conditions for the main factors involved in the HT acid hydrolysis process, using $\mathrm{H}_{3} \mathrm{PO}_{4}$ and $\mathrm{HNO}_{3}$ (5:5 ratio) concentrations between 45-720 mM, temperatures ranging between 120 $180^{\circ} \mathrm{C}$, hydrolysis times of $5-20 \mathrm{~min}$, and slurry concentrations between $8-20 \%(\mathrm{w} / \mathrm{v})$ as shown in Fig. 2 . The effects exerted by the varying $\mathrm{H}_{3} \mathrm{PO}_{4}$ and $\mathrm{HNO}_{3}$ (5:5 ratio) concentrations were determined at a temperature of
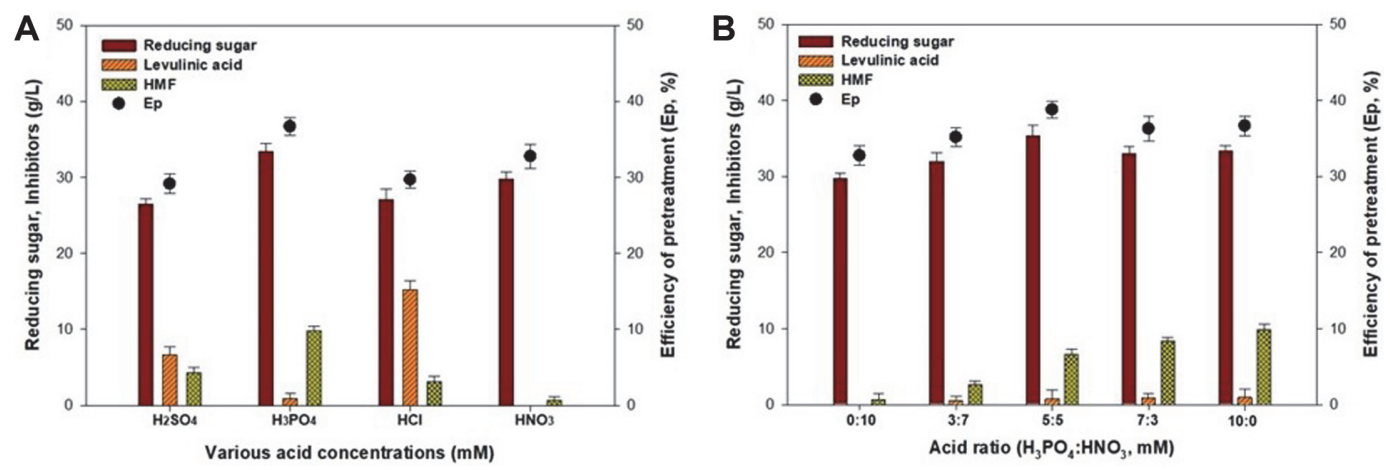

Fig. 1. The effect of (A) various acid types and (B) acid ratios on the production of reducing sugar from G. amansii by HT acid hydrolysis. HT acid hydrolysis was carried out with a slurry concentration of $12 \%(\mathrm{w} / \mathrm{v})$ and $360 \mathrm{mM}$ of acid at $160^{\circ} \mathrm{C}$ for $15 \mathrm{~min}$. 

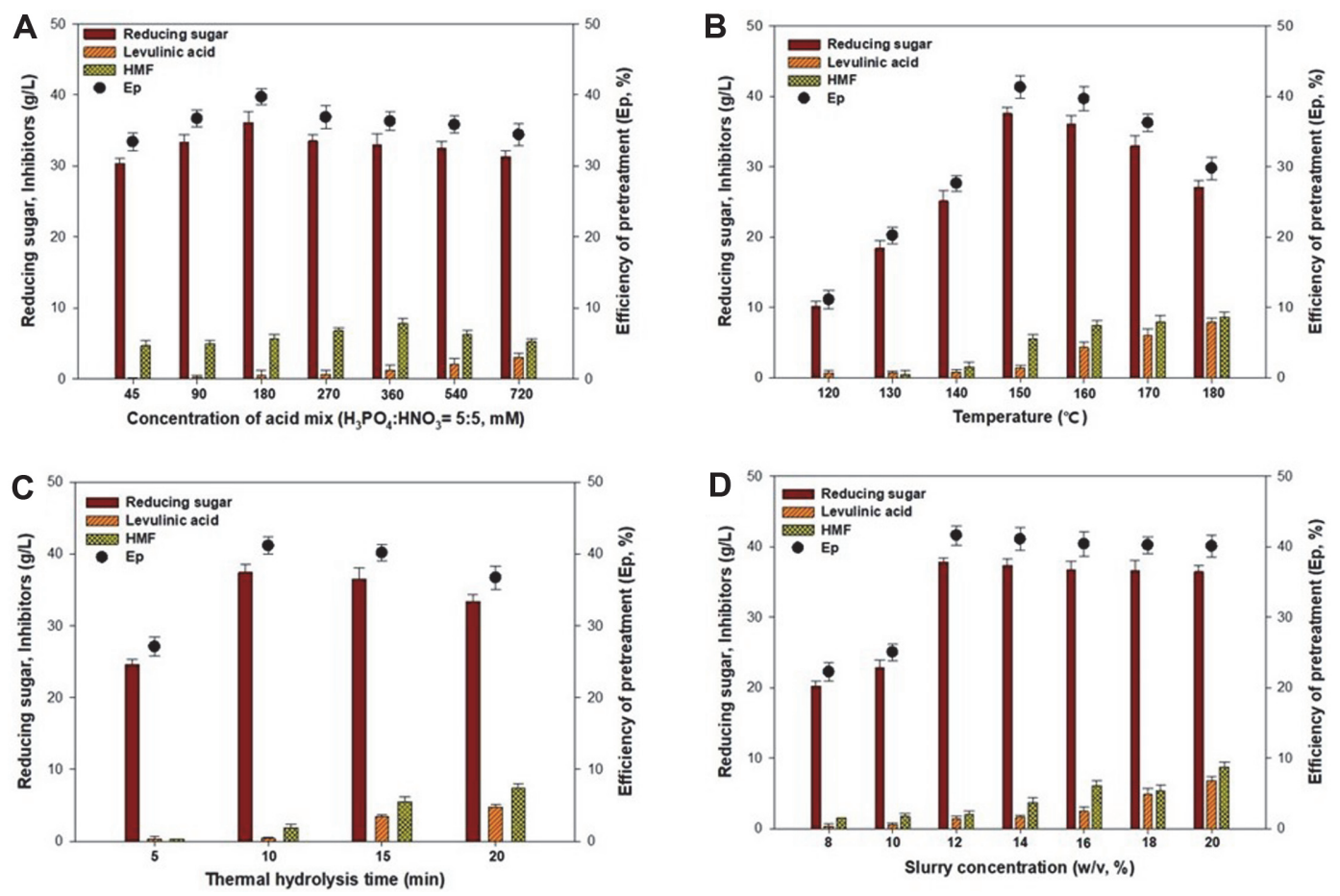

Fig. 2. The evaluation of the HT acid hydrolysis conditions by changing the process parameters: (A) concentration of the acid mix, (B) reaction temperature, (C) thermal hydrolysis time, and (D) slurry concentration.

$160^{\circ} \mathrm{C}$, thermal hydrolysis time of $15 \mathrm{~min}$, and $12 \%$ (w/v) slurry as shown in Fig. 2A. Our results showed that the reducing sugar concentration increased when increasing the concentration of the acid mixture to $180 \mathrm{mM}$. Therefore, the maximum reducing sugar concentration of $36.1 \mathrm{~g} / \mathrm{l}$ and an $E_{\mathrm{p}}$ of $39.7 \%$ were obtained when using an acid mixture concentration of $180 \mathrm{mM}$. Further increases in concentration did not lead to significant increases in reducing sugar concentrations. Notably, reducing sugar production was reduced when the concentration was higher than $180 \mathrm{mM}$. Therefore, an acid mixture concentration of $180 \mathrm{mM}$ was selected for HT acid hydrolysis pretreatment.

As shown in Fig. 2B, the temperature experiments were performed using $12 \%(\mathrm{w} / \mathrm{v})$ slurry, $180 \mathrm{mM}$ acid mixture, and a thermal hydrolysis time of $15 \mathrm{~min}$. Increasing the temperature from 120 to $150^{\circ} \mathrm{C}$ resulted in an increase in the concentration of reducing sugars. The maximum reducing sugar concentration was obtained at $150^{\circ} \mathrm{C}$, with $37.5 \mathrm{~g} / \mathrm{l}$ and an $E_{\mathrm{p}}$ of $41.3 \%$. However, increasing the temperature above $150^{\circ} \mathrm{C}$ resulted in a decrease in the concentration of reducing sugar, as well as an increase in the production of inhibitory compounds, such as 5 $\operatorname{HMF}(8.65 \mathrm{~g} / \mathrm{l})$ and levulinic acid $(7.87 \mathrm{~g} / \mathrm{l})$ at $180^{\circ} \mathrm{C}$. This indicates that excessive degradation of hexoses occurred at temperatures higher than $150^{\circ} \mathrm{C}$. Similar glucose decomposition during acid-catalyzed hydrothermal hydrolysis of pretreated Gelidium amansii was reported by Jeong et al. [20]. Therefore, $150^{\circ} \mathrm{C}$ was chosen as the optimal reaction temperature.

The effects of different thermal hydrolysis times were determined when performing $\mathrm{HT}$ acid hydrolysis using of $12 \%\left(\mathrm{w} / \mathrm{v}\right.$ ) slurry, $180 \mathrm{mM}$ of the acid mixture, and a reaction temperature of $150^{\circ} \mathrm{C}$ as shown in Fig. $2 \mathrm{C}$. Our results showed that the reducing sugar concentration increased when the thermal hydrolysis time was increased to $10 \mathrm{~min}$ and then decreased with a further increase from 10 to $20 \mathrm{~min}$. Similar results were obtained in other studies for the degradation of monosaccharides and the formation of inhibitory compounds by extended exposure to high temperature or a long thermal hydrolysis time [21]. Due to the reducing sugar concentrations and inhibitory effect of 5-HMF and levulinic acid, a $10 \mathrm{~min}$ thermal hydrolysis time was used in subsequent experiments.

The effects of using various slurry concentrations were determined at a temperature of $150^{\circ} \mathrm{C}$, thermal hydrolysis time of $10 \mathrm{~min}$, and an acid mixture concentration of $180 \mathrm{mM}$ as shown in Fig. 2D. We found that the $E_{\mathrm{p}}$ when using a slurry concentration of $12 \%(\mathrm{w} / \mathrm{v})$ was $41.6 \%$, with a reducing sugar production of $37.8 \mathrm{~g} / \mathrm{l}$. Increases in the slurry concentration during HT acid hydrolysis beyond $12 \%(\mathrm{w} / \mathrm{v})$ resulted in a decrease in the $E_{\mathrm{p}}$ from $41.6 \%$ to $40.0 \%$. Therefore, a slurry concentration of $12 \%(\mathrm{w} / \mathrm{v})$ was considered optimal for use in combination with the other parameters. These results indicate that the most effective HT acid hydrolysis conditions which prevent any damage to yeast fermentation were a slurry concentration of $12 \%(\mathrm{w} / \mathrm{v})$, an acid mixture concentration of $180 \mathrm{mM}$, a reaction temperature of $150^{\circ} \mathrm{C}$, and a reaction time of $10 \mathrm{~min}$.

On the other hand, the opposite effect was observed for 5-HMF [22]. Previous studies have reported that 5HMF was very useful not only as an intermediate for the production of biofuel, dimethylfuran (DMF) and other molecules, but also for the production of other important molecules such as levulinic acid, 2,5-furandicarboxylic 

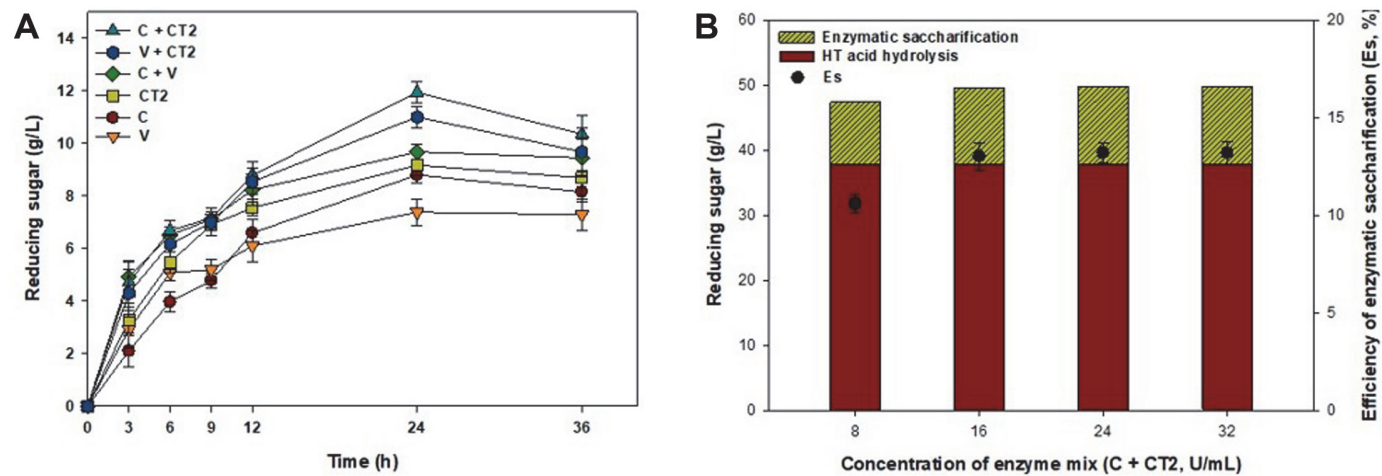

Fig. 3. The effect of the (A) enzyme type and (B) enzyme dosage on the reducing sugar release of the G. amansii hydrolysate when using $12 \%$ (w/v) slurry after $\mathrm{HT}$ acid hydrolysis at $\mathrm{pH} 5.0,40^{\circ} \mathrm{C}$ for $24 \mathrm{~h}$. The initial reducing sugar concentration after $\mathrm{HT}$ acid hydrolysis pretreatment was $37.8 \mathrm{~g} / 1$, where C is Celluclast $1.5 \mathrm{~L}, \mathrm{CT} 2$ is CTec 2, V is Viscozyme L, and Es is efficiency of enzymatic saccharification.

acid (FDA), 2,5-diformylfuran (DFF), dihydroxymethylfuran, and 5-hydroxy-4-keto-2-pentenoic acid. Thus, considerable efforts have been made to transform carbohydrates into 5-HMF [23, 24].

\section{Enzymatic Saccharification}

The effects of single and mixed enzyme treatments using enzyme concentrations of $16 \mathrm{U} / \mathrm{ml}$ after HT acid hydrolysis were evaluated, as shown in Fig. 3. The initial reducing sugar concentration after HT acid hydrolysis pretreatment was $37.8 \mathrm{~g} / \mathrm{l}$. As shown in Fig. 3A, our results revealed that the optimal enzyme reaction time was $24 \mathrm{~h}$ and a further increase in reaction time to $36 \mathrm{~h}$ had no significant effect on reducing sugar production. A single treatment with Celluclast $1.5 \mathrm{~L}$, Viscozyme L, or CTec2, led to an increase in reducing sugar concentration of $8.8 \mathrm{~g} / \mathrm{l}$ $\left(E_{\mathrm{s}}=9.7 \%\right), 7.4 \mathrm{~g} / \mathrm{l}\left(E_{\mathrm{s}}=8.1 \%\right)$, and $9.2 \mathrm{~g} / \mathrm{l}\left(E_{\mathrm{s}}=10.1 \%\right)$, respectively, as shown in Fig. 3A. However, treatment with a mixture of enzymes was shown to have a synergistic effect compared to the single enzyme treatments. Among the treatments, treatment with a mixture of Celluclast $1.5 \mathrm{~L}$ and CTec 2 was preferable to the other single and mixed enzyme treatments. Amamou et al. [25] reported that a mix of enzymes exhibited higher degradation activity compared to single-enzyme treatments. Thus, treatment with a mixture between Celluclast $1.5 \mathrm{~L}$ and CTec 2 was chosen for further experiments.

To determine the optimal dosage of the enzyme mix, enzymatic saccharification was carried out using various enzyme mixture activities $(8-32 \mathrm{U} / \mathrm{ml})$ at $50^{\circ} \mathrm{C}$ and $150 \mathrm{rpm}$ for $24 \mathrm{~h}$ as shown in Fig. 3B. The optimum enzymatic activity was $16 \mathrm{U} / \mathrm{ml}$ and further increases in enzyme activity up to $32 \mathrm{U} / \mathrm{ml}$ showed no significant effect on reducing sugar concentration. Therefore, the maximum reducing sugar concentration and $E_{\mathrm{s}}$ obtained were $12.0 \mathrm{~g} / \mathrm{l}$ and $13.2 \%$ using a dose of $16 \mathrm{U} / \mathrm{ml}$ of the Celluclast $1.5 \mathrm{~L}$ and CTec 2 mixture, respectively. Therefore, the enzyme mixture consisting of Celluclast $1.5 \mathrm{~L}$ and CTec2 at a concentration of $16 \mathrm{U} / \mathrm{ml}$ was selected for the enzymatic saccharification of the G. amansii hydrolysate. The efficiency of the pretreatment and enzymatic saccharification was $54.8 \%$, with $49.8 \mathrm{~g} / \mathrm{l}$ reducing sugar obtained from a total carbohydrate concentration of $90.96 \mathrm{~g} / \mathrm{l}$ and $120 \mathrm{~g} \mathrm{dcw} / \mathrm{L}$ of the G. amansii slurry.

\section{2,3-BD Fermentation by Engineered S. cerevisiae in G. amansii Hydrolysate}

The fermentation process was carried out by inoculating $6.8 \mathrm{~g} \mathrm{dcw} / \mathrm{L}$ of engineered $S$. cerevisiae into the HT acid-hydrolyzed and enzyme-hydrolyzed G. amansii slurry. As shown in Fig. 4, batch fermentation of engineered S. cerevisiae was carried out using a general thermal acid-hydrolyzed medium $\left(121^{\circ} \mathrm{C}\right.$ heat treatment for $\left.60 \mathrm{~min}\right)$ with $5.3 \mathrm{~g} / \mathrm{l}$ of 5-HMF (Fig. 4A), an HT acid-hydrolyzed medium with $1.9 \mathrm{~g} / \mathrm{l}$ of 5-HMF (Fig. 4B), and an HT acidhydrolyzed medium without 5-HMF using activated carbon (Fig. 4C).

As shown in Fig. 4A, the results for the fermentation process in the thermal acid-hydrolyzed medium with engineered S. cerevisiae showed a lag time of $48 \mathrm{~h}$ for 2,3-BD production due to the presence of 5-HMF. The 2,3$\mathrm{BD}$ concentration and the cell growth were increased from 60 to $108 \mathrm{~h}$ when the 5-HMF concentration was decreased to near zero during the fermentation process. Similar results were obtained for ethanol production. The presence of 5-HMF in concentrations close to zero in the fermentation broth resulted in a rapid uptake of reducing sugar, cell growth, and ethanol production [26]. The engineered S. cerevisiae fermentation in the thermal acidhydrolyzed medium produced $12.8 \mathrm{~g} / \mathrm{l} 2,3-\mathrm{BD}$ and a 2,3-BD yield $\left(Y_{\mathrm{BD}}, \mathrm{g} / \mathrm{g}\right)$ of 0.26 at $108 \mathrm{~h}$. As indicated by these results, the presence of an inhibitory compound influences not only the yeast strain, with respect to the sugar metabolic pathways, but also the formation of 2,3-BD during yeast fermentation. Jiang et al. [18] compared the yields of water-soluble products, reducing sugars, and furfurals (5-HMF and furfural) from Jatropha hulls. They reported that the furfural and 5-HMF present in the hydrolysates were inhibitors and removed them by charcoal adsorption during 2,3-BD fermentation. Thus, the presence of furfurals in the fermentation medium requires the separation of 5-HMF and furfural in detoxification steps.

As shown in Fig. 4B, we observed significant differences in the efficiency of the fermentation process when using the HT acid-hydrolyzed medium. The use of the HT acid-hydrolyzed medium with $1.9 \mathrm{~g} / \mathrm{l}$ of 5-HMF led to 

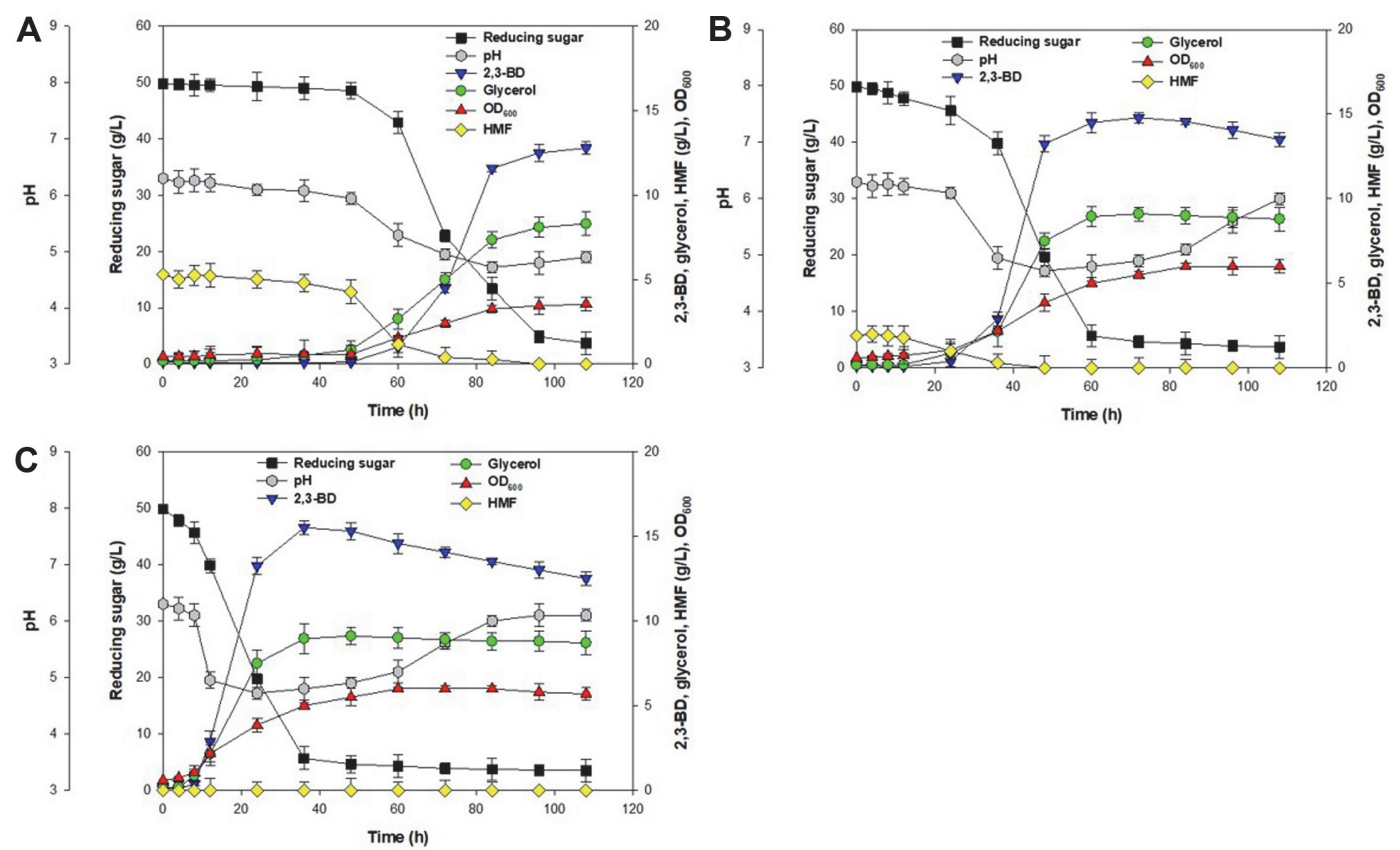

Fig. 4. 2,3-BD production from G. amansii by separate hydrolysis and fermentation (SHF) using engineered S. cerevisiae with (A) general thermal acid-hydrolyzed medium $\left(12^{\circ} \mathrm{C}\right.$ heat treatment for $\left.60 \mathrm{~min}\right)$ with $5.3 \mathrm{~g} / 15$ HMF, (B) HT acid-hydrolyzed medium with $1.9 \mathrm{~g} / 15-\mathrm{HMF}$, and (C) HT acid-hydrolyzed medium without 5HMF using activated carbon.

a reduction in the lag time from 48 to $24 \mathrm{~h}$ when compared to using a general thermal acid-hydrolyzed medium. Moreover, the reducing sugar was consumed until $60 \mathrm{~h}$ into the fermentation process, with a resulting 2,3-BD concentration and 2,3-BD yield coefficient of $14.8 \mathrm{~g} / \mathrm{l}$ and 0.30 at $72 \mathrm{~h}$, respectively. These results indicate that the decreased 5-HMF concentration successfully improved the efficiency of the production of 2,3-BD via fermentation of reducing sugar. Thus, HT acid hydrolysis pretreatment is important to obtain reducing sugar with a low concentration of inhibitory compounds when the G. amansii hydrolysate is used as the carbon source.

To further improve the efficiency of the 2,3-BD production process, the activated carbon was added to the seaweed hydrolysates, as shown in Fig. 4C. A volume of $100 \mathrm{ml}$ of the hydrolysate supplemented with 3\% (w/v) activated carbon was placed in a shaking water bath at $100 \mathrm{rpm}$ and $50^{\circ} \mathrm{C}$ for an adsorption time of $5 \mathrm{~min}$. This resulted in $100 \%$ of the 5 -HMF removal by activated carbon adsorption (data not shown) and a similar result was also obtained by a previous report [27]. Fig. $4 \mathrm{C}$ shows that after detoxification, the reducing sugar was consumed until $36 \mathrm{~h}$ and $3.5 \mathrm{~g} / \mathrm{l}$ of reducing sugar remained in the fermentation medium. The engineered S. cerevisiae produced 2,3-BD at a concentration of $15.5 \mathrm{~g} / \mathrm{l}$ and $Y_{\mathrm{BD}}$ of 0.31 during $36 \mathrm{~h}$ of fermentation. This indicates that the detoxification step can increase sugar utilization from seaweed hydrolysates, resulting in higher 2,3-BD yields in the fermentation broth. The 2,3-BD yield in this study was higher than that of the engineered S. cerevisiae BY4741, which has a $Y_{\mathrm{BD}}$ of 0.11 [28]. Thus, the use of activated carbon in G. amansii hydrolysates before fermentation has been shown to reduce the concentration of inhibitors effectively. This indicates that the engineered S. cerevisiae is a promising strain for increasing the 2,3-BD yield. Based on the obtained results, the evaluation of the HT acid hydrolysis process and the engineered $S$. cerevisiae strain could facilitate the efficient utilization of reducing sugar for the production of 2,3-BD from G. amansii hydrolysates.

In this study, HT acid hydrolysis was shown to produce significant reducing sugar concentrations and minimum inhibitory compounds. Therefore, 2,3 - $\mathrm{BD}$ fermentation could be conducted without any damage to the sugar metabolism of the engineered S. cerevisiae strain. Among the three enzyme treatments investigated, a mixture of Celluclast $1.5 \mathrm{~L}$ and $\mathrm{CTec} 2$ showed preferable result to the other single and mixed enzyme treatments for enzymatic saccharification. Notably, the 2,3-BD concentration and $Y_{\mathrm{BD}}$ produced using the engineered S. cerevisiae strain was $14.8 \mathrm{~g} / \mathrm{l}$ and 0.30 at $72 \mathrm{~h}$, respectively. The fermentation profiles of the engineered $S$. cerevisiae provided a basis for the production of 2,3-BD via fermentation using the G. amansii hydrolysate as a substrate.

\section{Acknowledgments}

The authors acknowledge Prof. Seo, JH of Seoul National University for his help in the research with the donation of engineered S. cerevisiae. This work was supported by the National Research Foundation of Korea(NRF) grant funded by the Korea government(MSIT) (No.2019R1G1A1007247). 


\section{Conflict of Interest}

The authors have no financial conflicts of interest to declare.

\section{References}

1. Serrano-Ruiz JC, West RM, Dumesic JA. 2010. Catalytic conversion of renewable biomass resources to fuels and chemicals. Annu. Rev. Chem. Biomol. Eng. 1: 79-100.

2. Nigam PS, Singh A. 2011. Production of liquid biofuels from renewable resources. Prog. Energy Combust. 37: 52-68.

3. Soltys KA, Batta AK, Koneru B. 2001. Successful nonfreezing, subzero preservation of rat liver with 2,3-butanediol and type I antifreeze protein. J. Surg. Res. 96: 30-34.

4. Celińska E, Grajek W. 2009. Biotechnological production of 2,3-butanediol: current state and prospects. Biotechnol. Adv. 27: 715-725.

5. Garg S, Jain A. 1995. Fermentative production of 2,3-butanediol: a review. Bioresour. Technol. 51: 103-109.

6. Sukwong P, Ra CH, Sunwoo IY, Tantratian S, Jeong GT, Kim SK. 2018. Improved fermentation performance to produce bioethanol from Gelidium amansii using Pichia stipitis adapted to galactose. Bioprocess Biosyst. Eng. 41: 953-960.

7. Kim SI, Seo SO, Jin YS, Seo JH. 2013. Production of 2,3-butanediol by engineered Saccharomyces cerevisiae. Bioresour. Technol. 146: $274-281$

8. Kim JW, Seo SO, Zhang GC, Jin YS, Seo JH. 2015. Expression of Lactococcus lactis NADH oxidase increases 2,3-butanediol production in Pdc-deficient Saccharomyces cerevisiae. Bioresour. Tehcnol. 191: 512-519.

9. Kildegaard KR, Wang Z, Chen Y, Nielsen J, Borodina I. 2015. Production of 3-hydroxypropionic acid from glucose and xylose by metabolically engineered Saccharomyces cerevisiae. Metab. Eng. Commun. 2: 132-136.

10. Ishida N, Saitoh S, Onishi T, Tokuhiro K, Nagamori E, Kitamoto, K, et al. 2006. The effect of pyruvate decarboxylase gene knockout in Saccharomyces cerevisiae on L-lactic acid production. Biosci. Biotechnol. Biochem. 70: 1148-1153.

11. Pronk JT, Steensma HY, vanDijken JP. 1996. Pyruvate metabolism in Saccharomyces cerevisiae. Yeast 12: 1607-1633.

12. Choi EJ, Kim JW, Kim SJ, Seo SO, Lane S, Park YC, et al. 2016. Enhanced production of 2,3-butanediol in pyruvate decarboxylasedeficient Saccharomyces cerevisiae through optimizing ratio of glucose/galactose. Biotechnol. J. 11: 1424-1432.

13. Flikweert MT, VanderZanden, L, Janssen WMTM, Steensma HY, VanDijken JP, Pronk J T. 1996. Pyruvate decarboxylase: an indispensable enzyme for growth of Saccharomyces cerevisiae on glucose. Yeast 12: 247-257.

14. AOAC (Association of Official Analytical Chemists). 1995. Official methods of analysis of the association of official analytical chemists, pp. 222-240. 16th edn. Association of Official Analytical Chemists, Arlington, VA, USA.

15. Irfan M, Nadeem M, Syed Q. 2014. One-factor-at-time (OFAT) optimization of xylanase production from Trichoderma viride-IR05 in solid-state fermentation. J. Radiat. Res. Appl. Sci. 7:317-326.

16. Nguyen TH, Sunwoo IY, Ra CH, Jeong GT, Kim SK. 2019. Acetone, butanol, and ethanol production from the green seaweed Enteromorpha intestinalis via the separate hydrolysis and fermentation. Bioprocess Biosyst. Eng. 42: 415-424.

17. Sukwong P, Sunwoo IY, Lee MJ, Ra CH, Jeong GT, Kim SK. 2019. Application of the severity factor and HMF removal of red macroalgae Gracilaria verrucosa to production of bioethanol by Pichia stipitis and Kluyveromyces marxianus with adaptive evolution. Appl. Biochem. Biotechnol. 187: 1312-1327.

18. Jiang LQ, Fang Z, Guo F, Yang LB. 2012. Production of 2,3-butanediol from acid hydrolysates of Jatropha hulls with Klebsiella oxytoca. Bioresour. Technol. 107: 405-410.

19. Li M, Li W, Lu Y, Jameel H, Chang H, Ma L. 2017. High conversion of glucose to 5-hydroxymethylfurfural using hydrochloric acid as a catalyst and sodium chloride as a promoter in a water/ $\gamma$-valerolactone system. RSC Adv. 7: 14330-14336.

20. Jeong TS, Choi CH, Lee JP, Oh KK. 2012. Behaviors of glucose decomposition during acid-catalyzed hydrothermal hydrolysis of pretreated Gelidium amansii. Bioresour. Technol. 116: 435-440.

21. Jeong GT, Ra CH, Hong YK, Kim JK, Kong IS, Kim SK, et al. 2015. Conversion of red-alage Gracilaria verrucosa to sugars, levulinic acid and 5-hydroxymethylfurfural. Bioprocess Biosyst. Eng. 38: 207-217.

22. Rosatella AA, Simeonov SP, Frade RFM, Afonso CAM. 2011. 5-Hydroxymethylfurfural (HMF) as a building block platform: Biological properties, synthesis and synthetic applications. Green Chem. 13: 754-793.

23. Saha B, Abu-Omar MM. 2014. Advances in 5-hydroxymethylfurfural production from biomass in biphasic solvents. Green Chem. 16: $24-38$.

24. Kougioumtzis MA, Marianou A, Atsonios K, Michailof C, Nikolopoulos N, Koukouzas N, et al. 2018. Production of 5-HMF from cellulosic biomass: Experimental results and integrated process simulation. Waste Biomass Valor. 9: 2433-2445.

25. Amamou S, Sambusiti C, Monlau F, Dubreucq E, Barakat A. 2018. Mechano-enzymatic deconstruction with a new enzymatic cocktail to enhance enzymatic hydrolysis and bioethanol fermentation of two macroalgae species. Molecules 23: 174-184.

26. Ra CH, Nguyen TH, Jeong GT, Kim SK. 2016. Evaluation of hyper thermal acid hydrolysis of Kappaphycus alvarezii for enhanced bioethanol production. Bioresour. Technol. 209: 66-72.

27. Ra CH, Jeong GT, Kim SK. 2016. Hyper-thermal acid hydrolysis and adsorption treatment of red seaweed, Gelidium amansii for butyric acid production with pH control. Bioprocess Biosyst. Eng. 40: 403-411.

28. Ng CY, Jung MY, Lee JW, Oh MK. 2012. Production of 2,3-butanediol in Saccharomyces cerevisiae by in silico aided metabolic engineering. Microb. Cell Fact. 11: 68-81. 